\title{
The Drivers of Demand for Non-Life Insurance
}

\author{
Nawaf A.Salem Alghusin ${ }^{1 *}$, Hamad A.Kasasbeh ${ }^{2}$ \\ ${ }^{1,2}$ Department of Finance and Banking, Faculty of Business, Zaytoonah University of Jordan, Amman, 11733, \\ Jordan
}

\begin{abstract}
:
The purpose of this study is to examine the main factors that may determine non-life insurance demand in Jordan during the period 1990 to 2015. The study employed multiple regression model. By applying OLS regression, it has been found that income level, population size, trade activity and interest rate have significant effect on demand for non-life insurance in Jordan. These results are consistent with most of empirical researches in this area.
\end{abstract}

Keywords: insurance demand, determination, OLS regression.

\section{Introduction}

Insurance industry plays an important role in economic growth in both developed and developing economies. The insurance market in Jordan is split between life and non-life insurance. Non-life insurance consists of marine insurance, fire insurance, motor vehicle insurance, health insurance, and accident insurance. Non-life insurance strongly dominants the insurance sector of Jordan, with contribution of $89 \%$ to the gross premium Witten in the country in 2015 (Central bank of Jordan 2016)

The insurance sector in Jordan continued to grow stately during the period 2000 to 2015. Total premiums registered $\$ 785.6$ million in 2015, rising from $\$ 142.4$ million in 2000 . The compound annual growth rate (CAGR) during the above period reached $11.6 \%$. Insurance penetration rate (premiums as as a ratio of GDP) is stil less than the world level amounting to about $6.23 \%$ where it has reached $2.3 \%$ in Jordan in 2015. The penetration ratio in Jordan is one of the highest rates in the Middle East and North Africa (MENA), which have a rate of $1.5 \%$ (Swiss Re 2016 , and Jordinvest 2016). 


\section{icallalme}

$2^{\text {nd }}$ International Conference on Advanced Research in

MUNICH, GERMANY BUSINESS, MANAGEMENT \& ECONOMICS

According to Arena (2003) "insurance market activity may promote economic growth by allowing different risk to be managed more efficiently. This will encourage the accumulation of new capital through mobilizing domestic saving into productive investment". Recent unpublished study has revealed that insurance sector in Jordan affect economic growth positively (Kasasbeh, 2017).

Although the insurance sector has grown significantly in Jordan during the last decades, in addition to its highly potential impact on Jordan economic growth, economic and insurance researchers have not paid much attention to the sector contribution in the economy. Also little has been known about the factors that may affect the demand for non-life insurance in Jordan. Therefore, this study is expected to fill the gap in literature by identifying the factors that determined the non-life insurance in Jordan.

Thus, it's the main purpose of this paper is to examine economic, social, demographic and other factors that may determine non-life insurance demand in Jordan. The results of this study are useful for domestic non-life insurance companies in developing their existing market as well as in choosing and delivering new insurance proudest. The result is also useful for policy makers in dealing with the impact of various factors on non-life insurance demand, which would help them in developing the sector thereby enhancing economic growth in the domestic economy.

The paper is organized as follows. Section 2 highlights literature on the determinants of the demand for non-life insurance. Section 3, presents the research methodology and data used in the analysis. The results of the empirical research are given in section 4. Finally, section 5 will offer some conclusions remarks.

\section{Literature Review}

Reviewing the previous studies that have been devoted to study the determinations of the demand for non-life insurance indicates that these studies consider the macroeconomic factors, demographic factors, and social factors, as the major factors influencing the demand for non-life insurance. Sherden (1984), beenstock et al. (1988), Brown et al. (2000), ward et al. (2004), Erike.E et al. (2011), Park et al. (2011), Treerattanapun (2011), Swiss Re(2012), Boubaker. K, et al. (2012), Poposki et al. (2013), S.L Oragos (2014),K . poposki et al. (2015), and Moboga C.K (2015).

Sherden (1984) conducted a study in order to analysis the termination of demand for Automobile insurance. The author used across sectional analysis of consumption limited to automobile 
insurance in the state of Massoachuseties in 1979. Results of the study indicate that income level has a positive impact on demand for motor insurance.

Beenstock, dickiuson and khajuria (1988), applied time series and cross section analysis over 12 years, covering 12 countries. The authors examined the relationship between property liability insurance premiums and income, interest rates. The found that income is related positively to premiums . Also, they have found that real interest rate correlated positively with the insurance premiums.

Browne, Chung, and frees (2000), study the factor influencing demand for general liability and motor vehicle insurance consumption across the () countries between 1987 and 1993. They found out that income and wealth influence demand for motor and liability insurance. Also, Esho et al. (2004) found that there is appositive relationship between income and expenses for property liability insurance.

Treeratattanapun (2011) found that for higher level of GDP per capita, non-life insurance becomes more affordable, thereby the demand for non-life insurance products rises as income of non-life insurance consumer's rise. Also, Park and Lemaire (2011) pointed out that education has a positive relationship with non-life insurance demand in about 82 countries for a period of 10 years.

The study of Erik.E, leste.E, and Rocha.R (2011) examines the determinants of insurance premiums (both life and non-life premiums) and total assets for a panel of about 90 countries during the period (2000-2008). The results show that income and trade activity have appositive and significant impact on demand for non-life insurance, while inflation has significant but positive impact on demand for non-life insurance. Population size was found to be significant has a negative impact on non-life demand for insurance.

Bhatia.B.S, and Yadav.B, (2013), Regressed non-life insurance indicators on various macroeconomic variable as such as inflation, population, money supply ratio to GDP and GNP. The results of the study show that GDP has positive and significant impact on the insurance density (non-life insurance per capital). Inflation and population have negative impact on nonlife insurance indicators, but inflation found to be insignificant.

Petkofski.M, and Kjosevski (2013) used an international data set for 16 countries from Central and South - Eastern Europe during the period 1988-2010 to identify determinants of the demand for non-life insurance. Their results show that GDP per capital, trade activity, and education level are the most predictors of the demand for non-life insurance. However, Inflation, and population density are not strongly associated with the non-life insurance demand. 


\section{icallalme}

$2^{\text {nd }}$ International Conference on Advanced Research in

MUNICH, GERMANY BUSINESS, MANAGEMENT \& ECONOMICS

Dragos S.L (2014), conduct a study on life and non-life insurance demand determination, and by using the econometrics of panel data on 17 emerging economies from Asia and Europe over a 10 year period. The results showed that there is a significant relationship between Education level and the demand for non-life insurance. Income is also found to be significant with non-life insurance demand.

Popski.K, Kjosevski.J, and Stojanovski.Z, (2015) conducted a study to examine the determination of non-life insurance penetration in 8 countries from South Eastern Europe during the period 1995-2011, applying a Panel Vector Error Correction Model (PVECM). The study results show that GDP per capita income positively and significantly influence the non-life insurance penetration. Inflation was found to have negative and significant impact on non-life insurance penetration, while population and education were found to have significant but negative impact on demand for non-life insurance.

Also, kjosevki.J, et al. (2015) examined the determinants of non-life insurance demand in 14 countries of Central and South - Eastern Europe between 1995 -2011 within Vector Error Correction Model (VECM). Empirical results of this study showed that the number of passenger cars, the role of law and GDP have positive and significant impact on non-life insurance demand.

According to Swiss Re (2012), the non-life insurance industries should manage the unexpected changes in interest rates. For example, in ease of unanticipated high interest rates, the industries can use renewal period in order to reprice their products, while in case of unanticipated low interest rules raising the prices of insurance policies would allow the non-life industries to restore profitability. This implies that the interest rates impact on the demand for non-life insurance would be of the opposite of that of inflation rates impact.

Following Boubaker.H, and Sghaier.N, (2012), The interest rates and inflation have a differential impact on the non-life insurance premiums depending on the value of inflation rate. During the inflationary period, the impact of the interest rates and inflation rate on the non-life insurance premiums are confirmed, positive and negative respectively. While in case of deflationary periods, the effect of interest rules and inflation rate on the non-life insurance will be negative and positive respectively.

\section{Methodology}

In this section, the study will investigate the key determinants of non-life insurance demand in Jordan. From the above literature review it can be shown that there are several macroeconomic variables and demographic variables have been widely examined and identified to affect the 


\section{icallalyme}

$2^{\text {nd }}$ International Conference on Advanced Research in

MUNICH, GERMANY

BUSINESS, MANAGEMENT \& ECONOMICS

demand for non-life insurance. For examples of these variables are income, inflation rate, interest rate, trade activity, population size, and education level. The OLS regression model has been employed as statistical tool for data analysis. The model to be used in the study is specified in line with the works of Petkovski.K, et al. (2013), Poposki.K, et al. (2015), and Kjosevki.J, et al. (2015), with some modifications. The functional relationship between non-life insurance demand and the above-mentioned variables is explored by considering the following equation.

$$
T P=B 0+B 1 . L N(G D P P e r)+B 2 . I R+B 3 . T O+B 4 . I+B 5 . P G+B 6 . S Y E+U
$$

Where, LN(GDPPER) is the natural logarithm, $U$ is the disturbance tern, and $\mathrm{B} 0, \mathrm{~B} 1, \mathrm{~B} 2, \mathrm{~B} 3, \mathrm{~B} 4, \mathrm{~B} 5$, and B6 are the coefficients to be estimated.

Annual time series data for the period 1990-2015 were collected from various sources. Table1, describes the measurement and source of data for variables.

Table 1. Variable Definition, Measurement, and Source of data

\begin{tabular}{|c|c|c|c|}
\hline Abbreviation & Variable & Measurement & Source of Data \\
\hline TP & Demand for non-life insurance & $\begin{array}{c}\text { Non-life insurance premiums as a } \\
\text { ratio of GDP }\end{array}$ & $\begin{array}{c}\text { Jordan Insurance federation } \\
\text { (JOIF) annual reports }\end{array}$ \\
\hline GDPPer & $\begin{array}{c}\text { Gross domestic product per } \\
\text { capital }\end{array}$ & Nominal GDP per capital & $\begin{array}{c}\text { Central bank of Jordan } \\
\text { (CBJ), yearly statistical } \\
\text { bulletin }\end{array}$ \\
\hline IR & Inflation rate & $\begin{array}{c}\text { Percentage of annual change in } \\
\text { consumer price index (CPI) }\end{array}$ & $\begin{array}{c}\text { Central bank of Jordan } \\
\text { (CBJ), yearly statistical } \\
\text { bulletin. }\end{array}$ \\
\hline TO & Trade activity & $\begin{array}{c}\text { Total (national exports + (total } \\
\text { imports) as a ratio of GDP }\end{array}$ & $\begin{array}{c}\text { Central bank of Jordan } \\
\text { (CBJ), yearly statistical } \\
\text { bulletin. }\end{array}$ \\
\hline I & Interest rate & $\begin{array}{c}\text { lending rate in commercial banks } \\
\text { Central bank of Jordan } \\
\text { (CBJ), yearly statistical } \\
\text { bulletin. }\end{array}$ \\
\hline SYE & Population size & Population growth rate & $\begin{array}{c}\text { Central bank of Jordan } \\
\text { (CBJ), yearly statistical } \\
\text { bulletin. }\end{array}$ \\
\hline
\end{tabular}




\subsection{Regression Results and Hypotheses Test}

Before starting discussion regression results, it's worth saying that since the used data represents time series covering the period (1990-2015), and with the probability of having a problem of instability over time, a unit root test was carried out for the data. By using Phillips- Peron (PP) unit root test, the results confirmed the conclusions reached in the appendix (2) that the data at their level not stationary but become stationary after the first differencing. Therefore, the all-time series for the variables under the study of order one 1(1) are integrated.

Also, according to the co-integration results presented in appendix (3), and since the trace statistics at the level of significant $5 \%$ are greater than a critical value, we, therefore, reject the null hypothesis which indicates that there is no cointegration between variables of the study. Thus, along run relationship could be conducted between non-life insurance demand (TP) and its determinates variables. Moreover, the multicollinearity test using the Variance Inflator Factor (VIF) indicates that no multicollinearity problem among independent variables. As shown in table (2), VIF is less than 10 and tolerance is greater than .10, then there is no multicollinearity problem.

Table (2) Variance Inflation Factor Test

\begin{tabular}{|c|c|c|}
\hline Variables & Tolerance & VIF \\
\hline Ln (GDPPer) & .391 & 2.536 \\
I & .232 & 4.311 \\
IR & .576 & 1.735 \\
SYE & .264 & 3.793 \\
TO & .486 & 2.056 \\
PG & .480 & 2.082 \\
\hline
\end{tabular}

The empirical results as shown in table (3) show that the variables included in the model explain $94.5 \%$ of the variation in the demand for non-life insurance (TP), as can be seen from the value of the coefficient of determination. The estimated model has prop probability (F-statistics) of 0.000 which shows that the independent variables altogether explain the dependent variable (TP) very well. Also, the estimation process is free of the autocorrelation problem as the DW coefficient indicates $(\mathrm{DW}=1.9)$. Based on the empirical results of the model, the following Hypotheses are tested as follows. 
$2^{\text {nd }}$ International Conference on Advanced Research in

Table (3) OLS regression results TP is the dependent variable.

\begin{tabular}{ccccc}
\hline \hline Variable & Coefficient & Std. Error & t-Statistic & \multicolumn{1}{l}{ Prob. } \\
\hline \hline Ln(GDPPer) & 0.003229 & 0.000697 & 4.631603 & 0.0002 \\
I & -0.000173 & 0.000264 & -0.655076 & 0.5207 \\
IR & -0.000225 & $5.56 \mathrm{E}-05$ & -4.051767 & 0.0007 \\
SYE & 0.002994 & 0.000513 & 5.838965 & 0.0000 \\
TO & 0.000139 & $1.73 \mathrm{E}-05$ & 8.028784 & 0.0000 \\
PG & 0.020931 & 0.009963 & 2.100845 & 0.0500 \\
C & -0.062238 & 0.010128 & -6.145406 & 0.0000 \\
\hline \hline R-squared & 0.944962 & Mean dependent var & 0.019131 \\
Adjusted R-squared & 0.926617 & S.D. dependent var & 0.003311 \\
S.E. of regression & 0.000897 & Akaike info criterion & -10.96399 \\
Sum squared resid & $1.45 \mathrm{E}-05$ & Schwarz criterion & -10.62270 \\
Log likelihood & 144.0498 & Hannan-Quinn criter. & -10.86933 \\
F-statistic & 51.50826 & Durbin-Watson stat & 1.900615 \\
Prob(F-statistic) & 0.000000 & & \\
\hline \hline
\end{tabular}

\subsection{Income level}

Ho: there is no significant effect of income level on non-life insurance demand.

The empirical results in table (3) show that GDP per capital regression coefficient is .00323 and the p-value is .0002. This result is consistent with the works of Sherden (1984), Beenstok et al. (1988), Browne et al. (2000), Esho, et al. (2004), Treeratattanapun (2011), Erik.E, et al. (2011), Bhatia.B.S, et al. (2013), Petkovski.M, et al. (2013), S.L.Dragos (2014), Poposki.K et al. (2015), and Kjosevki.J, et al. (2015). Based on this result, the researcher reject the null hypothesis that the income level and non-life insurance demand have no significant relationship, and accepts that income level has an impact on non-life insurance demand in Jordan.

\subsection{Education Level}


Ho: there is no significant effect of education level on non-life demand for insurance.

The empirical results in table (3) show that education level has positive and significant influence on non-life insurance demand in Jordan with regression coefficient .00299 and p-value of .0000. This result is consistent with the works of Treeratattanapun (2011), Petkovski.M, et al. (2013), and S.L.Dragos (2014). However, the findings of Poposki.K, et al. (2015), are not in line with this finding that shows significant but negative impact of education level on demand for non-life insurance. Therefore, based on the regression result, and on the most of empirical studies mentioned above, the researcher rejects the null hypothesis that the education level and the nonlife demand for insurance have no significant relationship, and accepts that education level has an impact on non-life insurance demand in Jordan.

\subsection{Trade activity}

Ho: there is no significant effect of trade activity on non-life insurance demand in Jordan.

The empirical results in table (3) show that trade activity has appositive and significant influence on non-life insurance demand in Jordan, with a regression coefficient .00014 and P-value of .0000. This result is consistent with the works of Erik.E, et al. (2011), and Petkovski.M, et al. (2013). Therefore, based on the regression result, the researcher rejects the null hypothesis that the trade activity and non-life demand for insurance have no significant relationship, and accepts that trade activity has an impact on non-life insurance demand in Jordan.

\subsection{Population size}

Ho: There is no significant effect of population size on non-life demand for insurance in Jordan.

The empirical results in table (3) show that population growth has appositive and significant influence on non-life insurance demand in Jordan, with a regression coefficient .021 and P-value of .0500. This result is coincident with the works of Petkovski.M et al. (2014). Therefore, based on the regression result, the researcher rejects the null hypothesis that the population size and non-life insurance demand have no significant relationship, and accepts that population size has an impact on non-life insurance demand in Jordan.

\subsection{Interest rate}

Ho: There is no significant effect of interest rate on non-life insurance demand. 
The empirical result in table (3) shows that interest rate has a negative and significant influence on non-life insurance demand in Jordan. Interest rate regression coefficient is .000225, and the P-value is .0007. The result of this study is in line with the work of Boubaker.H, and Sghaier.N (2012), and Swiss Re (2012). Therefore, based on the regression result, the researcher rejects the null hypothesis that the interest rate and non-life insurance demand have no significant relationship, and accepts that interest rate has a negative and significant impact on non-life insurance demand in Jordan.

\subsection{Inflation rate}

Ho: There is no significant effect of inflation rate on non-life insurance demand in Jordan.

The empirical results in table (3) show that inflation rate has a negative but not significant influence on non-life insurance demand in Jordan. Inflation rate regression coefficient is .000173 and the P-value is 0.5207. The result implies that there is no significant influence of inflation on non-life demand for insurance in Jordan. Therefore the null hypothesis that the inflation rate and non-life insurance demand have no significant that would be accepted. This results is no surprising because large part of non-life insurance activities in Jordan is subject to regulated prices, such as the price of third party car passengers insurance.

\section{Conclusions}

The study has examined the determinants of non-life insurance in Jordan in which is used multiple regression model, the analysis results have indicated that income level, education level, population size, trade activity, and interest rate affect the demand for non-life insurance in Jordan. Also, the results have shown that even though the inflation rate is negatively related to demand for non-life in Jordan, it has no significant impact on the non-life insurance demand.

The finding of this study has important implications on policy formulation for the policymakers of the marketing directors of the non-life insurance companies in Jordan. This finding may help them developing pricing strategies to achieve targeted sales for non-life insurance businesses.

\section{A ppendix (1):-}

Figare(1) appendis(1): historical devclopmeant of insuranes pentration (TP) over the period (1990-2015). 


\section{icallanme}

$2^{\text {nd }}$ International Conference on Advanced Research in

MUNICH, GERMANY

BUSINESS, MANAGEMENT \& ECONOMICS

6 - 8 DECEMBER, 2019

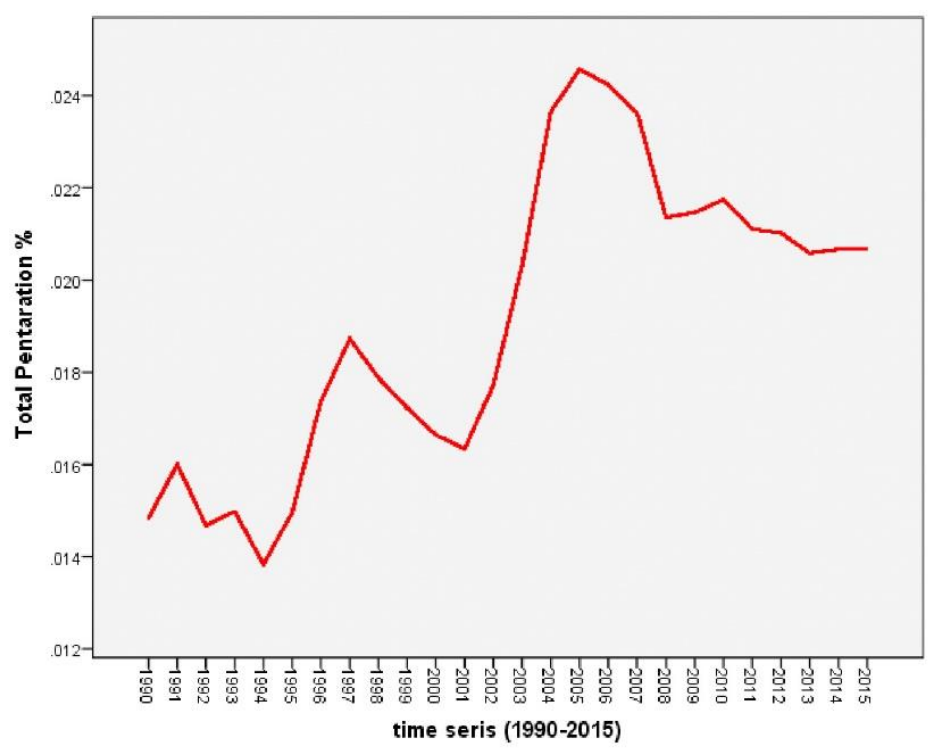

Figure(2) appendix(1): historical development of trade size (TO) over the period (1990-2015).

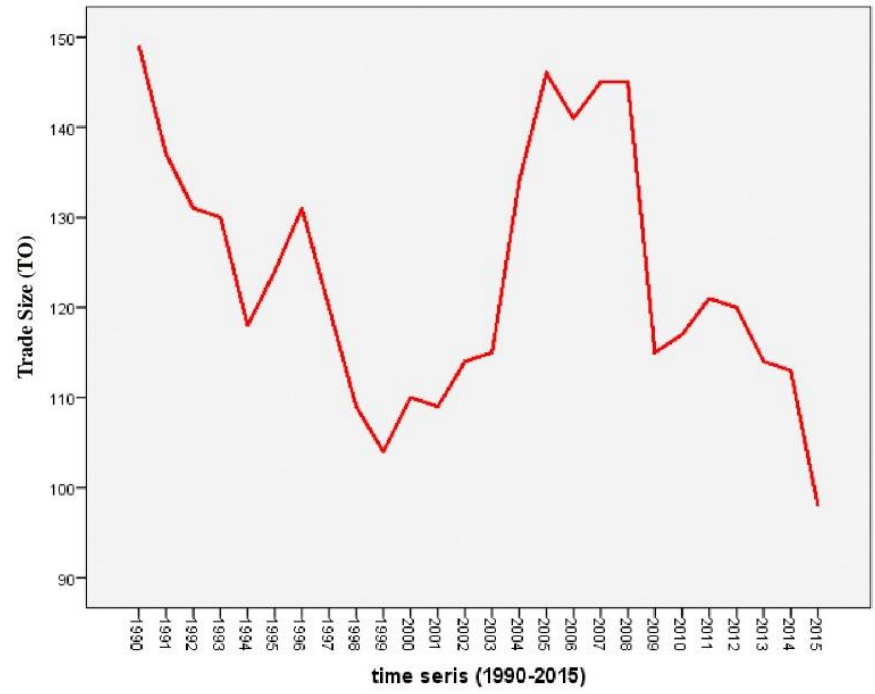




\section{icallalyme}

$2^{\text {nd }}$ International Conference on Advanced Research in

MUNICH, GERMANY

BUSINESS, MANAGEMENT \& ECONOMICS

Figure(3) appendix(1): historical development of percapita income, inflation rate, school year expected, and interest rate over the period (1990-2015).

LnGDPPer

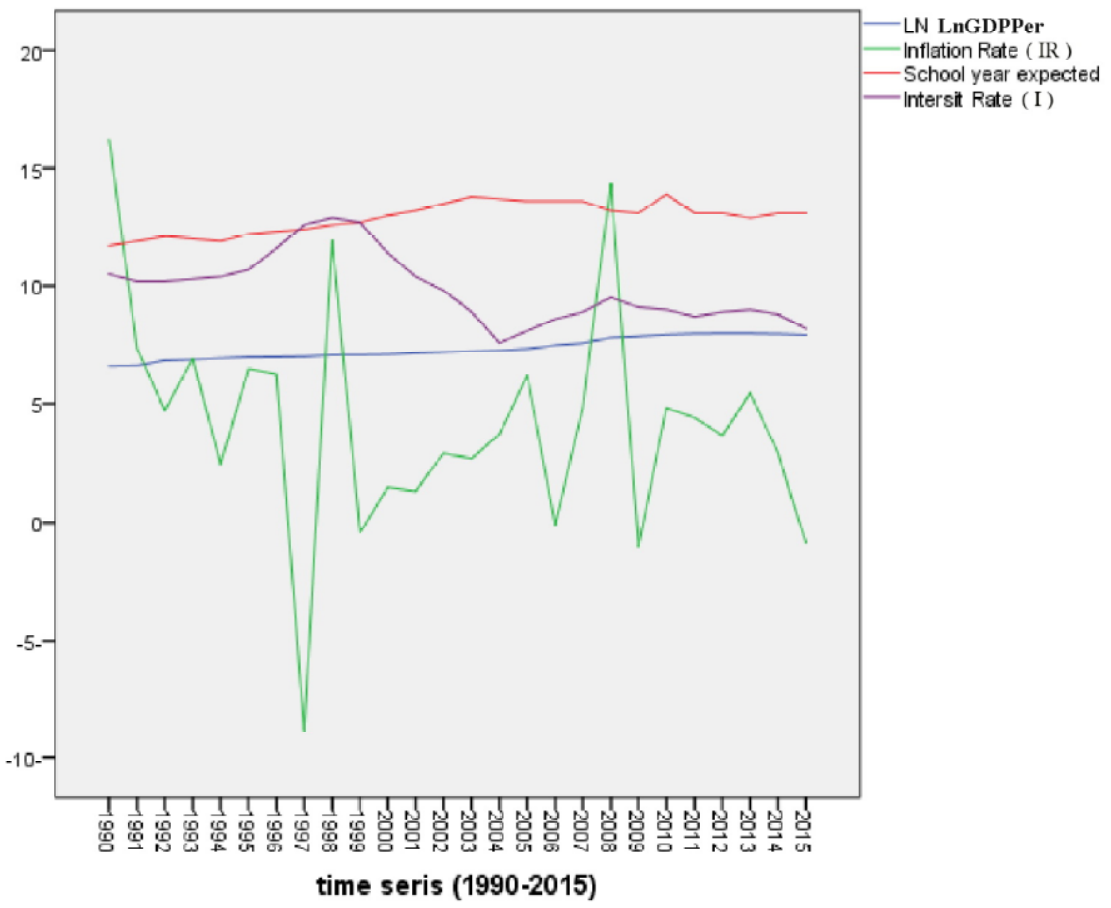

Figure (4) appendix (1): historical development of population growth over the period (1990-2015). 


\section{icallalyme}

$2^{\text {nd }}$ International Conference on Advanced Research in

MUNICH, GERMANY

BUSINESS, MANAGEMENT \& ECONOMICS

6 - 8 DECEMBER, 2019

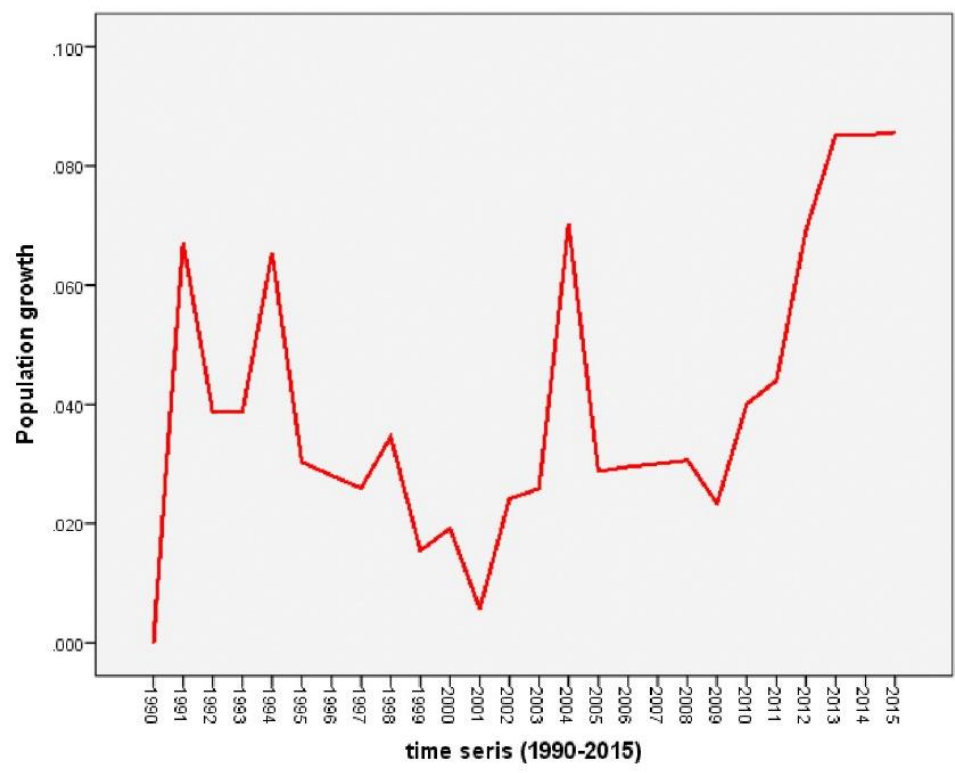

A appendix (2)

\begin{tabular}{|c|c|c|c|c|c|c|c|c|}
\hline \multicolumn{9}{|c|}{ UNIT ROOT TEST TABLE (PP) } \\
\hline \multicolumn{9}{|c|}{ At Level } \\
\hline & & ТP & LnGDPPer & $\mathrm{IL}$ & IR & SYE & TO & PG \\
\hline \multirow{3}{*}{ With Constant } & $\mathrm{t}$-Statistic & -1.5399 & -1.0696 & -0.8673 & -4.2368 & -1.9310 & -1.9104 & -2.8220 \\
\hline & Prob. & 0.4974 & 0.7113 & 0.7816 & 0.0033 & 0.3136 & 0.3224 & 0.0695 \\
\hline & & n0 & n0 & n0 & $* * *$ & n0 & n0 & $*$ \\
\hline \multirow{3}{*}{ With Constant \& Trend } & t-Statistic & -1.7542 & -1.5966 & -2.0969 & 4.1032 & -1.2488 & -1.9044 & -3.0974 \\
\hline & Prob. & 0.6961 & 0.7653 & 0.5225 & 0.0192 & 0.8773 & 0.6223 & 0.1284 \\
\hline & & n0 & n0 & n0 & $* *$ & n0 & n0 & n0 \\
\hline \multirow{3}{*}{ Without Constant \& Trend } & $\mathrm{t}$-Statistic & 0.4398 & 3.3054 & -1.1505 & -2.9698 & 1.0586 & -1.1873 & -0.2273 \\
\hline & Prob. & 0.8016 & 0.9994 & 0.2208 & 0.0048 & 0.9193 & 0.2084 & 0.5942 \\
\hline & & $\mathrm{n} 0$ & n0 & n0 & $* * *$ & n0 & $\mathrm{n} 0$ & n0 \\
\hline & & & & & & & & \\
\hline \multicolumn{9}{|c|}{ At First Difference } \\
\hline & & $\mathrm{d}(\mathrm{TP})$ & $\mathrm{d}$ (LnGDPPer) & $\mathrm{d}(\mathrm{IL})$ & $\mathrm{d}(\mathrm{IR})$ & $\mathrm{d}$ (SYE) & $\mathrm{d}(\mathrm{TO})$ & $\mathrm{d}(\mathrm{PG})$ \\
\hline \multirow{3}{*}{ With Constant } & $\mathrm{t}$-Statistic & -3.1279 & -3.7456 & -3.3912 & -9.0151 & -6.0225 & 4.1717 & -8.7245 \\
\hline & Prob. & 0.0378 & 0.0098 & 0.0216 & 0.0000 & 0.0000 & 0.0037 & 0.0000 \\
\hline & & $* *$ & $* * *$ & $* *$ & $* * *$ & $* * *$ & $* * *$ & $* * *$ \\
\hline \multirow{3}{*}{ With Constant \& Trend } & t-Statistic & -2.9727 & -3.8723 & -3.3294 & -10.7094 & -6.6112 & -4.0148 & -10.7599 \\
\hline & Prob. & 0.0296 & 0.0298 & 0.0855 & 0.0000 & 0.0001 & 0.0223 & 0.0000 \\
\hline & & $* *$ & $* *$ & $*$ & $* * *$ & $* * *$ & $* *$ & $* * *$ \\
\hline \multirow{3}{*}{ Without Constant \& Trend } & t-Statistic & -3.1648 & -2.4251 & -3.2550 & -7.1207 & -5.9206 & 4.1546 & -8.8728 \\
\hline & Prob. & 0.0029 & 0.0177 & 0.0023 & 0.0000 & 0.0000 & 0.0002 & 0.0000 \\
\hline & & $* * *$ & $* *$ & $* * *$ & $* * *$ & $* * *$ & $* * *$ & $* * *$ \\
\hline
\end{tabular}


$2^{\text {nd }}$ International Conference on Advanced Research in

Note:

1. accept null hypothesis: variable has a unit root if test value $>$ or (< absolute value) Critical Value

2. Include in test equation: (intercept).

\section{A appendix (3)}

Results of joint integration test method (Johansson)

\begin{tabular}{|l|c|c|c|}
\hline \multicolumn{1}{|c|}{ The test } & $\begin{array}{c}\text { The critical value } \\
\text { for the test at } 5 \%\end{array}$ & Calculated value & Prob. ${ }^{* *}$ \\
\hline Trace Statistic & $\mathbf{1 1 1 . 7 8 0 5}$ & $\mathbf{2 6 7 . 4 1 1 2}$ & $\mathbf{0 . 0 0 0}$ \\
\hline Max-Eigen Statistic & $\mathbf{4 2 . 7 7 2 1 9}$ & $\mathbf{8 3 . 7 4 7 9 3}$ & $\mathbf{0 . 0 0 0}$ \\
\hline
\end{tabular}

** At significant level at 5\%

\section{References:}

Arena.M, (2006), Doej insurance market Activity promotes Economic growth? A crosscountry for industrialized and developing countries. World Bank policy research paper 4028 Dee. 2006.

Brown,M, Chung J.W., and Frees,W (2000) international property - liability insurance consumption the Jordan of risk and insurances, 67 PP 73-90.

Beenstock,M., Dickinson, g., and Khajuria, S. (1988). The relationship between property liability insurance penetration and income: an international analysis. The journal of risk and insurance, 55 PP 259-272.

Boubaker.H., and Sghaire.N (2012) How do the interest rate and the inflation 5rate affect the non-life insurance premiums? BULLITIN France AIS'D Actuarial. Vol 12 no4 PP87-111.

Bhata.S.B., and Yadav.B (2013), non-life insurance in India: an Empirical analysis. Journal of Research in humanities and Social Science. Val (4) PP 2347-5404. 
Central bank of Jordan (CBJ), annual reports Amman 2016.

Central bank of Jordan (C13J) Annual statistical Bali tin , Amman Jordan 2016.

Esho,N, kirievsky, A., Ward,D., and Zurbruegg.R (2004), law and the determinants of property - casualty insurance. The journal of risk and insurance, 71 PP 256-283.

Fayen,E., Lester, R and Rocha, R. (2011). What drives the development of the insurance sector? An empirical analysis based on a panel of developed and developing countries. Policy research working paper presented at the World Bank. No 3572.

Jordan Insurance Federation (JO IF), Annual Reports, Amman Jordan different issues.

Jordan investment trust P.L.C (Jrodhvist), the Jordanian Insurance sector report. AmmanJordan October, 17, 2016.

Kjosevski.J., and Petkovski.M (2015). The determination of non- life insurance consumption otion: AVECM analysis in central and south - Eastern Europe. Acts economical, vol. 65(1), pp 107-127.

Petkivski,M., and Jordan.k., (2014) an analysis of non-life insurance determination for selected countries in central and south Eastern Europe: A con integration approach. Romanian journal of economic Forecasting - XVII (3) PP 160-177.

Poposki.K., Kjosevski.J., Stojanovski.Z., and Publikacji.J.(2015). The determination of nonlife penetration of non-life penetration in selected countries from south - Eastern Europe. Economic and Business Review. Vol (15) n 3. PP 20-37.

Sherden.W, (1984). An analysis of the determinants of the demand for auto mobile insurance. Journal of risk and insurance, 51. PP49-G2.

Samoan Laura drags (2014) life and non-life insurance demand the different effects of influence factors in emerging coquetries from Europe and Asia. Journal of Economic research - Ekonomska Intrazivanja vol 27, issue I, PP 169-180.

Treerattanapun. A (2011) the impact of culture on non- life insurance consumption paper presented are Wharton research scholars project, the university of Pennsylvania (Google scholar). 